Egyptian Journal of Rabbit Science, 22 (1) 1-21(2012)

\title{
UTILIZATION OF OLIVE PULP IN FEEDING NEW ZEALAND WHITE DOE RABBITS AND THEIR OFFSPRING UNDER THE CONDITIONS OF NORTH SINAI
}

\section{M.R. M.Mousa}

Department of Animal Production, Faculty of Environmental Agricultural Sciences, Suez Canal University, El-Arish, North Sinai, Egypt

\section{ABSTRACT:}

The effects of feeding four dietary treatments containing 0,20, 25 and $30 \%$ olive pulp without nucleolus as replacement for barley grains to does and growing rabbits on nutrients digestibility and nutritive values, productive and reproductive performance, growth performance and economical efficiency were studied.

The digestibility of DM, CP and $C F$ significantly $(P<0.05)$ decreased with increasing olive pulp level up to 30\%. However, digestibility of OM was not significantly affected by olive pulp inclusion. The gestation period, litter size at birth and at 28 days and litter weight at birth were insignificantly affected by olive pulp inclusion. The results indicated significant differences $(P<0.05)$ among treatments in bunny weight at birth, at 21days and at 28 days, litter weight at 21 days, at 28 days and at 35 days of age (weaning age), daily gain from birth to 21 days and from birth to 28 days and viability (\%) from birth to 21 days, from birth to 28 days and from birth to weaning. No significant differences were observed in total milk yield among doe rabbits fed olive pulp (OP). The growth performance traits, the daily body weight gain significantly $(P<0.05)$ decreased by increasing $O P$ level more than $25 \%$. Rabbits fed diets containing olive pulp can reduce production costs.

Accordingly, olive pulp without nucleolus could be used successively and safely instead of barley in feeding doe rabbits during gestation period up to $25 \%$, up to $20 \%$ during lactation period, and up to $25 \%$ for growing rabbits without adverse, under North Sinai conditions.

Key words: Olive pulp, digestibility, growth, reproduction, economical efficiency rabbits.

In Egypt, particularly in the new reclaimed desert lands, there is a great shortage in animal feedstuffs especially during summer season and early autumn (Yousef, 2005). The annual requirements of animal wealth in Egypt 
are about 14 million-ton of TDN and the shortage of animal feeds is about 4 million-ton of TDN (Mustafa et al., 2009). However, there are large amount of many agricultural by- products which are not efficiently utilized, such as olive pulp. In recent years, the cost of energy sources had dramatically increased with the increase of demand for animal feeding. The increase in feed prices encouraged nutritionists to search for cheaper feed ingredients having high energy (Suliman and Moustafa, 2008). The olive and olive- derived industries are of an special importance in the Mediterranean area (Martin Garcia et al., 2003). Olive pulp has high nutritive value and is available in large quantities in North Sinai (Mehrez and Mousa, 2011). Olive is extensively cultivated in the new reclaimed area in Egypt (Moustafa et al. 2008). From $1000 \mathrm{~kg}$ of fresh olives, about $214 \mathrm{~kg}$ olive oil, $496 \mathrm{~kg}$ crude olive cake, $40 \mathrm{~kg}$ of leaves and $1633 \mathrm{~kg}$ of olive mill waste water are produced (Vlyssides et al., 2004).

Feeding costs are the most significant expenses in animal production including rabbits and reaches $70 \%$ of the total costs of rabbits industry (ElSayaad, 2002). Incorporation of the cheap untraditional feedstuffs such as the agro- industrial wastes in animal diets may participate in solving the problem of feed shortage, decrease the feeding cost and alleviate the pollution problems (Moustafa et al., 2008).

Rabbits production has a potential in developing countries to supply cheap and high quality animal proteins within the shortest possible time. Rabbits are of small size, short generation interval, high reproductive potential, rapid growth rates, genetic diversity and ability to utilize forages and plant by - products as major diet components (El-Basiony et al., 2005). Rabbit meat is high in protein of excellent quality and low in total lipids, saturated fatty acids, cholesterol and sodium (Cheeke et al., 1987). Moreover, the annual production of female rabbit is about $35 \mathrm{~kg}$ of meat (comes from $60 \mathrm{~kg}$ live body weight of her offspring,( Wittouk et al., 1992), which is more than production of one ewe per year.

Olive by- products have been successively fed to rabbits (El-Kerdawy, 1997; Abd El-Galil, 2001; Abd El-Ghaffar, 2002; Mousa and Abdel-Samee, 2002; Abdel-Samee et al., 2005 and Mehrez and Mousa , 2011).

Therefore, the present study was carried out to investigate the effects of partial substitution of barley grains by olive pulp in does and growing rabbit's diets on nutrients digestibility, nitrogen balance, productive and reproductive performance, growth performance and economical efficiency, under the conditions of North Sinai, Egypt. 


\section{MATERIALS AND METHODS}

The present study was carried out at Rabbit Research Farm of Animal Production Department, Faculty of Environmental Agricultural Sciences, ElArish, Suez Canal University, during the period from March to June, 2009.

\section{Collection and preparation of olive pulp without nucleolus:}

Raw olive cake was collected from a local semi automatic olive pressing factory. The olive pulp was collected during the olive pressing season then transported to the Rabbit Research Farm. Olive pulp was spread on a plastic sheath for sun-drying. A few days later when the olive pulp was airdried, separation of seeds started. A $2 \mathrm{~mm}$ sieve was used in this process where almost all of the seeds were removed. Olive pulp obtained by sieving was placed in tight plastic sacs for later use.

The experimental work of this study was divided into three trials. The $\mathbf{1}^{\text {st }}$ trial was carried out to study the effect of partial substitution of barley grains by olive pulp without nucleolus on nutrients digestibility and nutritive values of bucks rabbits diets.

The 2nd trial was carried out to study the effect of partial substitution of barley grains by olive pulp in doe rabbit diets on their productive and reproductive performance.

The 3rd trial was carried out to study the effect of partial substitution of barley grains by olive pulp in growing rabbit diets on their growth performance.

In trial 1, 12 rabbit bucks were distributed according to their live body weight (average $3.52+0.02 \mathrm{~kg}$ ) into four experimental groups ( 3 buck rabbits per each). The four groups were assigned at random to receive the four experimental diets. The first group was given a commercial pelleted diet as a control, while groups 2,3 and 4 were fed diets containing either 20, 25 and $30 \%$ olive pulp without nucleolus to substitute $66.67,83.3$ and $100 \%$ of the barley in the control diet in diets 2,3 and 4 , respectively. Ingredients of the experimental diets are presented in Table 1. Rabbits were kept in individual metabolic cages. The digestibility trial consisted of 10 days preliminary period followed by 7 days as a collection period. The experimental diets were offered once a day at 8.00 a.m. During the collection period, total daily excreted feces were weighed and dried in an oven at $65^{\circ} \mathrm{C}$ for 48 hours. At the end of the collection period, dried feces of each buck were mixed, ground and kept in plastic vials for laboratorial analysis. Total daily urine excreted by each buck was collected in a jar containing $50 \mathrm{ml}$ of $20 \% \mathrm{H} 2 \mathrm{SO} 4$ to prevent ammonia loss. Daily samples of $20 \%$ were taken from each animal. Samples of feed, feces and urine were chemically analyzed according to A.O.A.C. (2010). 
Table 1. Formulation of the experimental diets (\% of the ingredients on DM basis).

\begin{tabular}{|c|c|c|c|c|}
\hline \multirow{2}{*}{ Ingredients } & \multicolumn{4}{|c|}{ Levels of olive pulp (\%) } \\
\hline & (Control) 0 & 20 & 25 & 30 \\
\hline Barley grains & 30.00 & 10.00 & 5.00 & - \\
\hline Olive pulp without nucleolus & - & 20.00 & 25.00 & 30.00 \\
\hline Wheat bran & 25.00 & 25.00 & 25.00 & 25.00 \\
\hline Soybean meal,44\% Cp & 17.00 & 17.00 & 17.00 & 17.00 \\
\hline Decorticated cottonseed meal & 5.00 & 5.00 & 5.00 & 5.00 \\
\hline Clover hay & 18.00 & 18.00 & 18.00 & 18.00 \\
\hline Molasses & 3.00 & 3.00 & 3.00 & 3.00 \\
\hline Limestone & 1.30 & 1.30 & 1.30 & 1.30 \\
\hline Sodium Chloride & 0.30 & 0.30 & 0.30 & 0.30 \\
\hline Premix* & 0.30 & 0.30 & 0.30 & 0.30 \\
\hline Dl-Methionine & 0.10 & 0.10 & 0.10 & 0.10 \\
\hline Total & $\mathbf{1 0 0 . 0 0}$ & $\mathbf{1 0 0 . 0 0}$ & $\mathbf{1 0 0 . 0 0}$ & $\mathbf{1 0 0 . 0 0}$ \\
\hline Digestible energy $(\mathrm{kcal} / \mathrm{kg})^{4}(\mathrm{DE})$ & 2728 & 2674 & 2660 & 2647 \\
\hline $\mathrm{Ca}$ & 0.40 & 0.63 & 0.71 & 0.76 \\
\hline Available Phosphorus (\% ) & 0.24 & 0.24 & 0.22 & 0.22 \\
\hline Lysine $(\%)$ & 0.85 & 0.76 & 0.76 & 0.75 \\
\hline Methionine (\%) & 0.25 & 0.22 & 0.21 & 0.20 \\
\hline Price per $100 \mathrm{~kg}(\mathrm{~L} . \mathrm{E})^{1}$ & 164 & 133 & 125 & 121 \\
\hline
\end{tabular}

*One kg of premix contained: Vit. A $4000.000 \mathrm{IU}$, Vit. 3D 5000.000 IU, Vit. E 16.70g, Vit. K $0.67 \mathrm{~g}$, Vit $\mathrm{B}_{1} 0.067 \mathrm{~g}$, Vit. $\mathrm{B}_{2} 2 \mathrm{~g}$, Vit. $\mathrm{B}_{6} 0.67 \mathrm{~g}$, Vit. $\mathrm{B}_{12} 0.004 \mathrm{~g}$, Niacin $16.7 \mathrm{~g}$, pantothinic acid $6.67 \mathrm{~g}$, Biotin 0.07g, folic acid 1.67g, Choline chloride $400 \mathrm{~g}, \mathrm{Zn} \mathrm{23.3g,} \mathrm{Mn10g,} \mathrm{Fe}$ $25 \mathrm{~g}, \mathrm{Cu} 1.67 \mathrm{~g}, \mathrm{I} 0.25 \mathrm{~g}$, Se $0.033 \mathrm{~g}$ and $\mathrm{Mg} 133.4 \mathrm{~g}$.

1.According to prices of the used ingredients at the experimental period (2009).

In trial 2, 32 New Zealand White (NZW) doe rabbits, according to weight and age, were randomly divided into four experimental groups ( 8 doe rabbits per each) during two parities from March to June. The average initial live body weight of the four groups were $3.25,3.21,3.15$ and $3.170 \mathrm{~kg}$, respectively.

Does were housed separately in individual wired cages $(60 \times 40 \times 35$ $\mathrm{cm}$ ) and raised $100 \mathrm{~cm}$ from the concrete floor. Each cage was provided with a natal box for kindling and nursing her young during the suckling period, and were provided with feeders and automatic nipple drinkers.

Feed and water were available ad-libitum. All rabbits were kept under the same managerial, hygienic and environmental conditions. Each doe was transferred to the cage of buck assigned for mating and returned back to her own cage after being mated and palpated for pregnancy 10 days after mating and those failed to conceive were returned back to the same mating buck to be remated within 12 hours, After kindling, litter size, litter weight and bunny weight were recorded. Gestation period (days), bunny weight at 14, 21, 
28 days and at weaning age, mortality rate and daily gain weight up to weaning were also recorded. Daily milk yield for each doe was measured individually twice / day (every 12 hours) by difference in weight of the pups after and before suckling. Averages of daily milk yield and total milk yield during the sucking period were recorded.

Trial 3 lasted for 42 days. A total number of 32 weaned NZW male rabbits (offspring from the dams of the second trial) were weighed $(941.5+$ $20.5 \mathrm{~g}$ ) and divided into four similar groups (8 each) which were randomly assigned to receive the same four experimental diets of trails1 and 2. Each two rabbits were housed in galvanized with commercial cages measured (40 x 40 $\mathrm{x} 25 \mathrm{~cm}$ ) and raised $120 \mathrm{~cm}$ from the concrete floor. The cages were provided with feeders and automatic drinkers. Feed and water were available adlibitum. All rabbits were kept under the same managerial, hygienic and environmental conditions. Individual live body weight and feed throughout the experimental period were weekly recorded. Body weight gain and feed conversion ratio were also calculated.

Economical evaluation: The economical efficiency (Y) was calculated according to El-Kerdawy (1997) and Mousa and Abd-Samee (2002):

$\mathrm{Y}=\mathrm{A}-\mathrm{B} / \mathrm{B}$, where: $\mathrm{A}$ is the selling cost of the obtain gain and $\mathrm{B}$ is the feeding cost of this gain.

\section{Statistical analysis:}

Data were subjected to statistical analysis by the SAS Computer Program (2004) using the General Linear Models (GLM). The model was used as follows:

$$
\mathrm{Yij}=\mu+\mathrm{Ti}+\mathrm{Eij}
$$

Where, Yij is the observation of $i j, u$ is the overall mean, Ti is the effect of $i$ (treatments) and Eij is the experimental random error.

Significance among treatment means were tested at 5\% level of probability using Duncan's multiple range tests (Duncan, 1955).

\section{RESULTS AND DISCUSSION}

\section{Chemical composition of the ingredients and experimental diets:}

The chemical composition on DM-basis of the ingredients used to formulate the experimental diets (Table 2) revealed that the $\mathrm{CP}$ content $10.20 \%$ ) of olive pulp without nucleolus used to replace barley grains in the 
Table 2. Chemical composition of the ingredients and the experimental Diets (on DM-basis).

\begin{tabular}{|l|c|c|c|c|c|c|c|}
\hline \multirow{2}{*}{ Ingredients } & DM & \multicolumn{6}{|c|}{ \% on DM basis } \\
\cline { 3 - 8 } & \% & OM & CP & EE & CF & NFE & Ash \\
\hline Olive pulp without nucleolus & 91.50 & 93.45 & 10.20 & 9.34 & 19.45 & 54.46 & 6.55 \\
Barley grains & 90.43 & 97.52 & 9.30 & 1.85 & 7.10 & 79.27 & 2.48 \\
Diet 1 (control) & 90.53 & 92.30 & 17.84 & 2.29 & 11.9 & 60.27 & 7.70 \\
Diet 2 & 90.61 & 91.49 & 18.02 & 3.78 & 14.47 & 55.22 & 8.51 \\
Diet 3 & 90.67 & 91.28 & 18.06 & 4.16 & 15.11 & 53.95 & 8.72 \\
Diet 4 & 90.70 & 91.08 & 18.11 & 4.54 & 15.75 & 52.68 & 8.92 \\
\hline
\end{tabular}

experimental diet (was within the normal ranges ( 8.7 to $12 \%$ ) published by (Salama et al., 1993 ; Ghazalah and El-Shahat 1994; Rabayaa et al.,2001; Mousa and Abdel-Samee, 2002, Mostafa et al., 2003 and Mehrez and Mousa, 2011). However, it was higher than those reported by Mousa and Shetaewi, 2002; Abou El-Naser and El-Kerdawy, 2003; Molina - Alacaide and YanezRuiz, 2008; Moustafa et al. 2008 and Mustafa et al., 2009. Such differences may be due to the type of olive, stage of maturity, location and methods of preparation.

The removal of seeds from olive pulp increased the crude protein and decreased crude fiber of the olive pulp (Rabayaa et al. (2001). In addition, ether extract for olive pulp (9.34\%) was within the normal range (8.91 to 12.0\%) published by Abdel-Galil, (2001); Rabayaa et al., (2001); Lotfollahian and Hosseini, (2007) ; Moic et al. (2007) and Merez and Mousa (2011), but it was lower than those reported by Abou El-Naser and El-Kerdawy, (2003) and Mustafa et al. (2009). It was, however, higher than the values reported by Abdel -Ghaffar , (2002), Mousa and Abel-Samee, (2002) ; Mousa and Shetawei , (2002); Martin - Garcia et al., (2003); Molina - Alcaide and Yanez- Ruiz, (2008) and Moustafa et al., (2008). Differences in the chemical composition can be due to the oil extraction process, degree of extraction, year and geographical origin of olives (Moic et al., 2007). One of the main limiting factors for the use of olive cake in the feed of domestic animals is its variable chemical composition (Molina Alcaide et al., 2003).

Crude protein (CP), ether extract (EE); crude fiber (CF) and ash were higher in olive pulp without nucleolus than barley grains, while nitrogen free extract (NFE) was lower than that of barley grains (Table 1). These results are in agreement with those reported by El-Kerdawy (1997), Abdel-Ghaffar (2002) and Mehrez and Mousa (2011). The proximate analysis of the consumed experimental diets is also shown in Table 1. The control diet had higher NFE\% but lower EE (2.29) and CF (11.9\%) than diets 2, 3 and 4. 
These results are in agreement with those giving by El-Kerdawy (1997); Abd El-Galil (2001); Mousa and Abdel-Samee (2002); Mostafa et al., (2003)1 Moic et al., (2007); Moustafa et al., (2008) and Mustafa et al. (2009).

\section{Nutrients digestibility and nutritive values:}

Nutrients digestibility of the experimental diets are presented in Table 3. Apparent digestibility of DM, CP, EE, CF and NFE for the different experimental diets were significantly different $(\mathrm{P}<0.05)$. The digestibility of $\mathrm{CP}$ and $\mathrm{CF}$ were significantly $(\mathrm{P}<0.05)$ lower in diet $4(30 \%)$ OP compared with other experimental diets.

Table 3. Digestion coefficients and feeding values of the experimental diets.

\begin{tabular}{|c|c|c|c|c|}
\hline \multirow{2}{*}{ Items } & \multicolumn{4}{|c|}{ Levels of olive pulp (\%) } \\
\hline & (Control) 0 & 20 & 25 & 30 \\
\hline \multicolumn{5}{|c|}{ Digestion coefficient (\%): } \\
\hline DM & $65.70 \pm 1.12^{\mathrm{ab}}$ & $66.21 \pm 1.14^{\mathrm{a}}$ & $65.92 \pm 1.34^{\mathrm{ab}}$ & $62.83 \pm 1.73^{\mathrm{b}}$ \\
\hline OM & $69.07 \pm 0.95$ & $68.91 \pm 1.22$ & $67.8 \overline{6} \pm 0.86$ & $65.02 \pm 1.70$ \\
\hline $\mathrm{CP}$ & $73.41 \pm 0.53^{\mathrm{a}}$ & $73.80 \pm 0.68^{\mathrm{a}}$ & $72.65 \pm 0.52^{\mathrm{a}}$ & $70.05 \pm 0.42^{\mathrm{b}}$ \\
\hline $\mathrm{EE}$ & $72.39 \pm 1.38^{\mathrm{c}}$ & $76.02 \pm 1.17^{\mathrm{b}}$ & $80.25 \pm 0.55^{\mathrm{a}}$ & $80.55 \pm 1.33^{\mathrm{a}}$ \\
\hline $\mathrm{CF}$ & $43.93 \pm 0.25^{\mathrm{a}}$ & $42.25 \pm 0.38^{\mathrm{ab}}$ & $41.33 \pm 0.16^{\mathrm{ab}}$ & $40.58 \pm 1.54^{\mathrm{b}}$ \\
\hline NFE & $77.10 \pm 0.38^{\mathrm{a}}$ & $73.20 \pm 1.50^{\mathrm{b}}$ & $71.07 \pm 1.37^{\mathrm{bc}}$ & $68.91 \pm 0.78^{\mathrm{c}}$ \\
\hline \multicolumn{5}{|c|}{ Nutritive values } \\
\hline TDN $\%$ & $68.51 \pm 0.22^{\mathrm{a}}$ & $66.29 \pm 1.01^{\mathrm{ab}}$ & $65.22 \pm 0.80^{\mathrm{bc}}$ & $63.60 \pm 0.82^{c}$ \\
\hline $\mathrm{DE}(\mathrm{kcal} / \mathrm{kg})$ & $3020.0 \pm 15.30^{\mathrm{a}}$ & $2930.8 \pm 43.80^{\mathrm{ab}}$ & $2883.17 \pm 34.05^{\mathrm{bc}}$ & $2811.0 \pm 35.62^{\mathrm{c}}$ \\
\hline DCP \% & $13.09 \pm 0.09^{\mathrm{a}}$ & $13.29 \pm 0.12^{\mathrm{a}}$ & $13.12 \pm 0.09^{\mathrm{a}}$ & $12.68 \pm 0.08^{\mathrm{b}}$ \\
\hline
\end{tabular}

Insignificant differences were observed among diets 1,2 and 3 in the digestibility of DM, CP and CF. However, diets 4 (30\% olive pulp) showed the lowest digestibility for DM , OM, CP, CF and NFE. These results are in agreement with those of Ben Rayana et al.(1994); Abd El-Galil (2001); Abd El-Rahman et al., (2003); Mostafa et al. (2003); Moustafa et al. (2008); Mustafa et al. (2009) and Mehrez and Mousa (2011). They reported that the digestibility of nutrients were decreased with increasing olive pulp inclusion in the diet.

In this respect, Aguiliera (1987) reported that the decrease in digestibility of $\mathrm{CP}$ and $\mathrm{CF}$ may be attributed to the relatively high lignin content of olive pulp and the fact that most of its total nitrogen is linked to lignocelluloses which are the two main factors limiting the digestive utilization of olive residues. 
The digestibility of EE was significantly $(\mathrm{P}<0.05)$ higher in diet 3 and 4 (25 and 30\% op) compared to the control diet. These results are in agreement with those reported by El-Kerdawy (1997) and Mustafa et al. (2009). The high EE digestibility of such diets (72.39 to $80.55 \%$ ) indicated the good ability of rabbits to utilize dietary fat (Beyen, 1988 , Igwebuike et al., 2008 and Mehrez and Mousa, 2011).

The digestibility of NFE was significantly $(\mathrm{P}<0.05)$ higher for diet $1(77.10 \%)$ compared to other experimental diets. Similar trend have been reported by Abd El-Galil (2001). The higher NFE digestibility $(\mathrm{P}<0.05)$ in diet 1 (control) may than other tested diets be due to high digestibility of barley based diets due to the high availability of their carbohydrates. These results are in agreement with those reported by Cheeke et al. (1987); Onifade and Tewe (1993) and Igwebuike et al. (2008) who noted that the high digestibility of corn- based diets was due to the high availability of their carbohydrates. Moreover, Lotfollahian and Hosseini (2007) reported that the olive pulp either with or without nucleolus can be considered as good energy source.

The previous results obtained of nutrients digestibility are supported by the findings of El-Kerdawy (1997) with rabbits. Also, Tortuero et al. (1989) found that digestibility of $\mathrm{CP}$, neutral and acid detergent fiber was reduced with $30 \%$ olive pulp diet, however, no changes were recorded with 10 or $20 \%$ OP diets compared with the control with rabbits.

It is clear that replacing $100 \%$ of the barley by olive pulp in present study lowered the digestible protein content. This may be due to the chemical nature of olive pulp crude protein beside its content of some antinutritional factors (tannins) Mustafa et al.,(2009). These results are parallel to those reported by Youssef et al. (2001) and Moustafa et al. (2008).

Table (4) illustrates the nutritive values of the experimental diets expressed as TDN\%, DCP\% and DE (kcal/kg). The nutritive value expressed as TDN and DE\% significantly $(\mathrm{P}<0.05)$ decreased as olive pulp inclusion rates reached 30\%. Also, Mustafa et al. (2009) reported that TDN was markedly reduced with increasing level of OP in the Lambs diet. Similarly, Mostafa et al. (2003); Youssef (2009) and Mehrez and Mousa (2011) reported that nutrients digestibility and feeding value of diets were decreased with increasing level of OP in diets of rabbits.

Moreover, the reductions in nutrient digestibility of OP diets were explained by Mustafa et al. (2009) to be probably due to:

1 - The negative effect of more complex tannins in OP.

2- High content of lignin and other poorly digested components.

3-Most of total nitrogen in OP is linked to lignocellulose compounds.

4- The high content of ADL and ADF in OP. 
Table 4. Nitrogen balance of NZW rabbit bucks fed the experimental diets.

\begin{tabular}{|ccccc|}
\hline \multirow{2}{*}{ Items } & \multicolumn{4}{c|}{ Levels of olive pulp (\%) } \\
\cline { 2 - 5 } & (Control) 0 & $\mathbf{2 0}$ & $\mathbf{2 5}$ & $\mathbf{3 0}$ \\
\hline $\mathrm{N}-$ intake $(\mathrm{g} / \mathrm{h} / \mathrm{d})$ & $2.75+0.02$ & $2.64+0.11$ & $2.52+0.08$ & $2.48 .+0.03$ \\
Fecal $-\mathrm{N}(\mathrm{g} / \mathrm{h} / \mathrm{d})$ & $0.83+0.02$ & $0.79+0.05$ & $0.80+0.07$ & $0.76+0.09$ \\
N-digested $(\mathrm{g} / \mathrm{h} / \mathrm{d})$ & $1.92+0.04 \mathrm{a}$ & $1.85+0.06 \mathrm{ab}$ & $1.72+0.03 \mathrm{~b}$ & $1.73+0.06 \mathrm{~b}$ \\
Urinary-N $(\mathrm{g} / \mathrm{h} / \mathrm{d})$ & $0.93+0.11$ & $0.98+0.07$ & $1.07+0.04$ & $1.05+0.05$ \\
N-balance $(\mathrm{g} / \mathrm{h} / \mathrm{d})$ & $0.99+0.07 \mathrm{a}$ & $0.87+0.02 \mathrm{a}$ & $0.65+0.01 \mathrm{~b}$ & $0.57+0.01 \mathrm{~b}$ \\
NB/NI x 100 & $36.00+2.51 \mathrm{a}$ & $32.92+1.58 \mathrm{a}$ & $25.79+0.99 \mathrm{~b}$ & $22.98+0.10 \mathrm{c}$ \\
NB/ND x 100 & $51.95+4.82 \mathrm{a}$ & $47.03+1.90 \mathrm{a}$ & $37.79+1.39 \mathrm{~b}$ & $33.14+1.41 \mathrm{~b}$ \\
\hline
\end{tabular}

a.b \&c: means bearing different superscripts within the same row differ significantly $(\mathrm{P}<0.05)$.

No significant differences in TDN\% were observed among diet 1 control and 2 (20\% op). Similar results were obtained by El-Kerdawy (1997); Moustafa et al. (2008) and Mehrez and Mousa (2011).

Insignificant differences were observed among dietary treatments for DCP \% of diets 1, 2and 4. While, Moustafa et al. (2008) reported a significant decrease in DCP when lactating buffaloes were fed diet including $30 \%$ OP.

However, El-Sayed et al. (1996) and Moustafa et al. (2008) found that the values of TDN and DCP for diets contained 25 to $30 \%$ of olive pulp were lower than those contained 15 to $20 \%$ level of olive pulp. Nitrogen balance:

The data of N-balance recorded for the rabbits fed the four experimental diets are presented in Table 4. In general, all rabbits fed the four experimental diets were in positive $\mathrm{N}$-balance. The $\mathrm{N}$-balance was higher $(\mathrm{P}<0.05)$ for rabbits receiving either the control diet or the diet containing 20\% OP compared with those on the $25 \%$ or $30 \%$ OP. Finally, N-balance was decreased with increasing olive pulp inclusion in the diets. These results are in agreement with those reported by Mehrez and Mousa (2011).

\section{Reproductive performance:}

Reproductive performance of NZW doe rabbits are presented in Table 5. There were no significant differences in gestation period for the four diets. The gestation period of does used in the experiment was within the normal ranges (30.2 to 32 day) published in Egypt (Salwa et al., 1999; Hussein et al., 1999; Bassuny, 1999; and Mousa and Shetawei, 2003).

Gestation length was nearly similar in all experimental diets and ranged between 31.0 to 31.50 days. These results confirmed the finding of Sarhan (1995) and Mahmoud et al. (1998). 
Table 5. Reproductive traits of doe NZW rabbits as affected by dietary olive pulp levels during the experimental periods.

\begin{tabular}{|c|c|c|c|c|}
\hline \multirow{2}{*}{ Items } & \multicolumn{4}{|c|}{ Levels of olive pulp meal (\%) } \\
\hline & (Control) 0 & 20 & 25 & 30 \\
\hline \multicolumn{5}{|l|}{ Doe weight after } \\
\hline \multirow[t]{2}{*}{ Kindling (kg) } & 3.12 & 3.09 & 2.91 & 3.04 \\
\hline & \pm 0.06 & \pm 0.13 & \pm 0.11 & \pm 0.08 \\
\hline Conception rate $(\%)$ & 87.5 & 87.5 & $\overline{7} 5.00$ & $\overline{7} 5.00$ \\
\hline \multirow[t]{2}{*}{ Gestation period (days) } & 31.0 & 31.12 & 31.13 & 31.50 \\
\hline & +0.19 & \pm 0.37 & \pm 0.18 & \pm 0.27 \\
\hline \multicolumn{5}{|l|}{ Litter size: } \\
\hline \multirow[t]{2}{*}{ At kidding } & 7.30 & 7.63 & 6.94 & 6.87 \\
\hline & \pm 0.19 & \pm 0.24 & \pm 0.45 & \pm 0.41 \\
\hline \multirow[t]{2}{*}{ At 14 days } & 6.03 & 6.57 & 5.69 & 5.65 \\
\hline & +0.61 & +0.28 & \pm 0.35 & \pm 0.38 \\
\hline \multirow[t]{2}{*}{ At 21 days } & 5.86 & 6.03 & 5.45 & 4.37 \\
\hline & \pm 0.62 & +0.52 & \pm 0.32 & \pm 0.42 \\
\hline \multirow[t]{2}{*}{ At 28 days } & 5.40 & 5.55 & 5.00 & 3.97 \\
\hline & \pm 0.64 & \pm 0.50 & \pm 0.28 & \pm 0.43 \\
\hline \multirow[t]{2}{*}{ At weaning } & 5.07 & 5.08 & 4.25 & 3.18 \\
\hline & $\pm 0.67^{\mathrm{a}}$ & $\pm 0.56^{\mathrm{a}}$ & $\pm 0.27^{\mathrm{ab}}$ & $\pm 0.40^{\mathrm{b}}$ \\
\hline \multirow[t]{2}{*}{ Age of weaning $(\mathrm{d})$} & 35.00 & 35.00 & 35.00 & 35.00 \\
\hline & \pm 0.54 & \pm 0.52 & \pm 0.57 & \pm 0.45 \\
\hline \multicolumn{5}{|l|}{ Litter weight } \\
\hline \multirow[t]{2}{*}{ At birth } & 383.95 & 393.81 & 362.5 & 333.17 \\
\hline & \pm 19.03 & \pm 7.39 & \pm 23.37 & \pm 24.82 \\
\hline \multirow[t]{2}{*}{ At 14 days } & 1286.27 & 1296.92 & 1193.17 & 1062.25 \\
\hline & \pm 121.59 & \pm 81.48 & \pm 58.96 & \pm 60.10 \\
\hline \multirow[t]{2}{*}{ At 21 days } & 1699.75 & 1558.26 & 1343.70 & 965.1 \\
\hline & $\pm 101.85^{\mathrm{a}}$ & $\pm 72.4^{\mathrm{a}}$ & $\pm 108.2 \mathrm{ab}$ & $\pm 149.36^{\mathrm{b}}$ \\
\hline \multirow[t]{2}{*}{ At 28 days } & 2614.91 & 2361.31 & 2093.38 & 1552.12 \\
\hline & $\pm 209.7^{\mathrm{a}}$ & $\pm 155.88^{\mathrm{a}}$ & $\pm 121.98 \mathrm{ab}$ & $\pm 176.4^{\mathrm{b}}$ \\
\hline \multirow[t]{2}{*}{ At weaning (35days) } & 3354.26 & 3025.7 & 2622.1 & 1886.16 \\
\hline & $\pm 328.06^{\mathrm{a}}$ & $\pm 227.26^{\mathrm{a}}$ & $\pm 344.58 \mathrm{ab}$ & $\pm 349.6^{\mathrm{b}}$ \\
\hline
\end{tabular}

A \& b: means bearing different superscripts within the same row differ significantly $(\mathrm{P}<0.05)$.

The results showed that does fed diets containing $0 \%$ and $20 \%$ olive pulp had better conception rate than those fed $25 \%$ and $30 \%$ OP. However, the differences were not significant.

Results clearly indicated that litter size at kidding, 14, 21 and 28 days were not significantly influenced by olive pulp inclusion, while litter size at weaning significantly $(\mathrm{P}<0.05)$ decreased as olive pulp inclusion 
rate was $30 \%$ of the diet. There were improvements in litter size at weaning in doe rabbits fed diets containing 0 or $20 \%$ olive pulp.

Body weight of the doe rabbits post kindling and reproductive performance are shown in Table 5. Body weight of the doe rabbits post kindling and litter weights at birth and 14 days did not differ significantly among different dietary treatments. While, litter weight at 21 days, 28 days and weaning significantly $(\mathrm{P}<0.05)$ decreased with increasing $30 \%$ OP inclusion in the diet. The adverse effect of OP on litter weight at 28 days and weaning may be attributed to lignin content of OP and the fact that most of its total nitrogen is linked to lignocellulose which are the two main factors limiting the digestive utilization of olive residues (Aguilera, 1987). Also, high level of OP may lead to lower palatability for bunny, which was reflected on the lower feed intake by bunnies and according decreased in litter weight. However, the differences in reproductive efficiency between does fed 20 and 25\% OP and those fed the control diet were not significant.

On the other hand, Abdel Ghaffar (2002) and Abdel-Samee et al. (2005) reported that litter weight at 21 day of age and at weaning of heat stressed California and NZW adult female rabbits increased significantly $(\mathrm{P}<0.05)$ in groups fed diets containing $20 \%$ OP than in control diet.

The average bunny weight at birth, daily weight gain and viability at all ages are presented in Table 6. Bunny weights (at birth, 14, 21 and 28 days and weaning), daily weight gain (from birth to 14 days and to weaning) and viability (from birth to 14 days and to 28 days and to weaning) were insignificantly affected when OP represented 20 or $25 \%$ of the diet compared to the control. While, these values were significantly $(\mathrm{P}<0.05)$ decreased when the diet included $30 \%$ OP. Moreover, bunny weight at 14 days, daily gain from birth to 14 days and viability \% from birth to 14 days did not differ significantly among different dietary treatments.

Results concerning effects of OP as untraditional source of energy on the reproductive performance of doe rabbits are agreed with the findings of Abdel Ghaffar (2002) and Abdel-Samee et al. (2005).

Data in Table (7) show that there were no significant differences in milk production for doe rabbits fed diets containing $0,20,25$, and $30 \%$ OP during suckling period. These results are in agreement with those obtained by Mousa and Shetaewi (2002) and Moustafa et al., (2008). Mousa and Shetwaei (2002) reported that OP replacement up to $30 \%$ of the lactating ewes diet did not significantly affect total milk yield and average daily milk yield. Also, Moustafa et al. (2008) reported insignificant differences among treatments for actual and 7\% fat - corrected milk yield of Egyptian lactating buffaloes fed rations containing OP compared to the control 
Table 6. Effect of feeding olive pulp on young traits of NZW rabbits.

\begin{tabular}{|lcccc|}
\hline \multirow{2}{*}{ Items } & \multicolumn{4}{c|}{ Levels of olive pulp (\%) } \\
\cline { 2 - 5 } & (Control)0 & $\mathbf{2 0}$ & $\mathbf{2 5}$ & $\mathbf{3 0}$ \\
\hline Bunny weight at & 53.16 & $51.94 \pm 1.64^{\mathrm{ab}}$ & $58.71 \pm 1.83^{\mathrm{a}}$ & $48.77 \pm 1.27^{\mathrm{b}}$ \\
& $\pm 2.40^{\mathrm{ab}}$ & & & \\
14 days & 218.12 & 201.21 & 225.17 & 191.17 \\
& \pm 7.39 & \pm 7.10 & \pm 7.69 & \pm 6.21 \\
21 days & 344.03 & 291.06 & 309.6 & 256.4 \\
& $\pm 18.2^{\mathrm{a}}$ & $\pm 21.2^{\mathrm{ab}}$ & $\pm 15.06^{\mathrm{ab}}$ & $\pm 8.91^{\mathrm{b}}$ \\
28 days & 498.60 & 441.64 & 435.42 & 397.12 \\
& $\pm 24.28^{\mathrm{a}}$ & $\pm 37.38^{\mathrm{ab}}$ & $\pm 19.02^{\mathrm{ab}}$ & $\pm 13.86^{\mathrm{b}}$ \\
Weaning & 676.08 & 618.37 & 637.35 & 591.38 \\
& \pm 23.63 & \pm 38.64 & \pm 61.33 & \pm 23.91 \\
\hline Daily weight gain from & & & & \\
Birth to 14 days & 11.35 & 10.24 & 11.87 & 10.17 \\
Birth to 21 days & \pm 0.58 & \pm 0.60 & \pm 0.56 & \pm 0.41 \\
Birth to 28 days & 16.55 & 12.83 & 12.66 & 10.75 \\
Birth to weaning & $\pm 0.78^{\mathrm{a}}$ & $\pm 0.85^{\mathrm{b}}$ & $\pm 0.61^{\mathrm{b}}$ & $\pm 0.46^{\mathrm{b}}$ \\
& 16.49 & 14.43 & 13.95 & 12.90 \\
Viability, \% from & $\pm 0.96^{\mathrm{a}}$ & $\pm 1.25^{\mathrm{ab}}$ & $\pm 0.73^{\mathrm{ab}}$ & $\pm 0.59^{\mathrm{b}}$ \\
Birth to 14 days & 17.80 & 16.18 & 16.53 & 15.50 \\
Birth to 21 days & \pm 0.64 & \pm 0.61 & \pm 1.29 & \pm 0.62 \\
\hline Birth to 28 days & 82.54 & 85.93 & 82.16 & 81.92 \\
Birth to weaning & \pm 6.21 & \pm 1.86 & \pm 3.64 & \pm 1.51 \\
& 80.47 & 78.81 & 79.34 & 63.68 \\
Daily feed intake (g/doe/d) & 250.02 & 248.41 & 245.95 & 243.25 \\
\hline
\end{tabular}

a.b. means bearing different superscripts within the same row differ significantly $(\mathrm{P}<0.05)$

animals. In contrast, Christodoulou et al. (2007) found that average milk yield tended to $(\mathrm{P}<0.01)$ decrease with increased fermented olive wastes feeding of lactating ewes. On the other hand, Abdel Ghaffar (2002) and Abdel-Samee et al. (2005) reported that feeding of heat stressed rabbits with OP meal increased $(\mathrm{P}<0.05)$ total milk yield during the suckling period compared to the control group.

Total milk yield values were 4517, 4795, 4895 and $4345 \mathrm{~g} /$ doe in suckling period for does fed diets containing $0,20,25$ and $30 \mathrm{OP}$, 
Table 7. Milk yield of NZW doe rabbits as affected by feeding varying olive pulp levels during the experimental periods.

\begin{tabular}{|lcccc|}
\hline \multirow{2}{*}{ Items } & \multicolumn{4}{c|}{ Experimental diets, OP (\%) } \\
\cline { 2 - 5 } & (Control) 0 & $\mathbf{2 0}$ & $\mathbf{2 5}$ & $\mathbf{3 0}$ \\
\hline Milk yield $(g)$ & & & & \\
Birth -14 days & 1685.83 & 1887.67 & 1990.8 & 1729.56 \\
& \pm 78.93 & \pm 103.87 & \pm 81.10 & \pm 113.50 \\
14 -28 days & 2049.5 & 2140.25 & 2142 & 2075.36 \\
& \pm 109.43 & \pm 111.41 & \pm 31.50 & \pm 92.29 \\
Birth -28 days & 3735.33 & 4027.92 & 4032.8 & 3804.92 \\
& \pm 93.4 & \pm 199.51 & \pm 77.71 & \pm 132.74 \\
Birth-weaning & 4517.17 & 4795.42 & 4895 & 4344.73 \\
& \pm 139.34 & \pm 207.30 & \pm 132.74 & \pm 269.87 \\
Weaning age(day) & 35.00 & 35.00 & 35.00 & 35.00 \\
& \pm 0.54 & $\underline{ \pm 0.52}$ & \pm 0.57 & \pm 0.45 \\
\hline
\end{tabular}

All the differences between treatment groups were not significant.

respectively. The highest value was that of diet 3 (25\% OP) followed by diet 2 (20\% OP), 1 (control) and 4 (30\% OP). The low total milk yield value of diet $4(30 \% \mathrm{OP})$ may be due to its high level of OP.

Growth performance and economical efficiency:

Results of live body weight (LBW), body weight gain (BWG), feed intake, feed conversion and economical efficiency as affected by the level of olive pulp are shown in Table 8. Rabbits fed the control diet showed non significant increase in final body weight in comparison with groups 3 and 4. Similar results were obtained by Tortuero et al. (1989), Ben Rayana et al. (1994); El-Kerdawy (1997); Mousa and Abd El-Samee (2002) and Mehrez and Mousa (2011).

Mehrez and Mousa (2011) found no significant differences in final live body weight, total body weight gain, daily body weight gain and feed conversion (feed/gain) of rabbits fed diets containing 0, 20, 25 and $30 \%$ olive pulp. The results showed insignificant total body weight gain and daily body weight gain for rabbits fed diets containing 0,20 and $25 \%$ olive pulp. It is noticed that daily body weight gain significantly $(\mathrm{P}<0.05)$ decreased by increasing olive pulp level more than $25 \%$.

In this connection, Moic et al. (2007) reported that the high level of olive cake inclusion $(30 \%)$ decreased $(\mathrm{P}<0.01)$ daily gain and final weight of lambs.

On the other hand, Gad et al. (2008) reported that the average of body weight gain was $11.29 \%$ higher for calves received $30 \%$ OP +20 yellow maize than those of control calves which received $50 \%$ yellow maize. Moreover, Mustafa et al. (2009) reported that average daily gain 
Table 8. Growth performance and economical efficiency of growing NZW rabbits as affected by dietary treatments.

\begin{tabular}{|c|c|c|c|c|}
\hline \multirow{2}{*}{ Items } & \multicolumn{4}{|c|}{ Levels of olive pulp, OP(\%) } \\
\hline & (Control) 0 & 20 & 25 & 30 \\
\hline Number of rabbits & 8 & 8 & 8 & 8 \\
\hline \multirow{2}{*}{ Intial body weight (g) } & 902.5 & 928.5 & 974.84 & 907.14 \\
\hline & \pm 22.74 & \pm 62.85 & \pm 56.08 & \pm 25.00 \\
\hline \multirow{2}{*}{ Final body weight (g) } & 1958.8 & 1964.3 & 1888.3 & 1721.4 \\
\hline & \pm 76.65 & \pm 98.39 & \pm 75.06 & \pm 52.03 \\
\hline \multirow{2}{*}{ Total body weight gain (g) } & 1056.25 & 1035.71 & $\overline{9} 13.50$ & 814.29 \\
\hline & $\pm 60.37^{\mathrm{a}}$ & $\pm 59.68^{\mathrm{a}}$ & $\pm 26.17^{\mathrm{ab}}$ & $\pm 58.92^{\mathrm{b}}$ \\
\hline Daily body weight gain(g) & $\begin{array}{r}25.15 \\
+1.34^{\mathrm{a}}\end{array}$ & $\begin{array}{r}24.66 \\
+1.75^{\mathrm{a}}\end{array}$ & $\begin{array}{c}21.7 \\
+0.57^{\mathrm{ab}}\end{array}$ & $\begin{array}{c}19.39 \pm 1.3 \\
0^{\mathrm{b}}\end{array}$ \\
\hline \multirow{2}{*}{ Daily feed intake (g) } & 89.60 & 89.80 & 87.22 & 82.21 \\
\hline & \pm 6.78 & \pm 7.18 & \pm 6.26 & \pm 6.12 \\
\hline Feed cost /kg gain (LE) & 5.83 & 5.01 & 5.25 & 5.28 \\
\hline Feed conversion (fFed/gain) & 3.56 & 3.64 & 4.01 & 4.24 \\
\hline Economical efficiency & 328.57 & 413.18 & 375.57 & 373.20 \\
\hline Improvement,$\%$ & 100 & 125.75 & 114.30 & 113.58 \\
\hline Mortality, \% & - & 12.5 & 12.5 & 12.50 \\
\hline
\end{tabular}

was improved by 6 and $8 \%$ for lambs fed diet supplemented with 10 and $20 \%$ OP for 105 days.

The same trend was reported by Ghazalah and Shaat (1994) who reported a significant increase in live body weight and weight gain of rabbits when fed olive kernel meal (OKM) to replace $50 \%$ of barley, while it was significantly reduced when (OKM) replaced 75 and $100 \%$ of barley .

Moreover, Abdel-Ghaffar (2002) reported a significant $(\mathrm{P}<0.05)$ increase in live body and daily body weight gain for California and New Zealand White growing rabbits fed (20\% olive pulp) as substitute of barley during hot summer by 19.60 and 20.30 and 42.6 and $47.1 \%$, respectively compared with rabbits fed the conventional diet (control). Also, Abd-Alla et al. (2007) reported that feeding olive pulp during hot summer season resulted in non significant improvements in growth rate of lambs. Christodoulou et al. (2008) observed insignificant final body 
weight, body weight gain, DM intake or feed conversion for lambs fed diets containing $0,5,10$ and $15 \%$ fermented olive wastes.

From the economical point of view, feeding growing rabbits diets containing 20, 25 and $30 \%$ olive pulp decreased the cost of feed per $\mathrm{kg}$ gain by $14.07,9.95$ and $9.43 \%$, while the economical efficiency values were raised with olive pulp supplementation by $25.75,14.30$ and 13.58 $\%$, respectively, compared with rabbits fed the control diet. The same trend was noticed for the improvement $\%$, the values were $100,125.75$, 114.30 and 113.58, respectively. These findings are in good agreement with those reported by El-Kerdawy (1997); Rabayaa et al. (2001), Mousa and Abdel-Samee (2002) and Abd El-Gaffar (2002). They are also in agreement with Mousa (2000 and 2001); Fayed et al. (2001); AbdelRahman et al. (2003) Abou El-Naser and El-Kerdawy (2003); and Mostafa et al. (2003) who found that the feed cost per $\mathrm{kg}$ gain was relatively lower than the control when lambs were fed diets contained 15$35 \%$ olive cake. Also, Moustafa et al. (2008) found that the economical efficiency (price of the $7 \%$ fat corrected milk produced/cost of the consumed feed) was lower than the control when Egyptian lactating buffaloes were fed diets containing $10-30 \%$ olive pulp. Conclusively, it could be concluded that olive pulp without nucleolus could be successively and safely included up to $25 \%$ of the pregnant rabbit diets without adverse effects on reproductive and productive performance and up to $20 \%$ during suckling period without any adverse effects on growth performance of bunnies. In addition, olive pulp could be fed to growing rabbits up to $25 \%$ without adverse effects on growth performance and decreased the cost of feed per $\mathrm{kg}$ gain.

However, further studies are required to arrive at the optimal level of olive pulp replacement for doe rabbits during suckling period.

Coclusively, olive pulp without nucleolus could be used successively and safely instead of barley in feeding doe rabbits during gestation period up to $25 \%$, up to $20 \%$ during lactation period, and up to $25 \%$ for growing rabbits without adverse, under North Sinai conditions, Egypt.

\section{REFERENCES}

Abd-Alla, O.A.M.; Abdel-Samee, A.M. and El-Adawy, S.I. (2007). Effect of Acacia saligna and olive pulp on growth biochemical and hormonal status in lambs under heat stress in Sinai Province. Suez Canal Veterinary, Medicine Journal, XII (2), 129-138. 
Abdel-Ghaffar, M. A.(2002). Improving productivity of heat stressed rabbits using genetic and nutritional techniques under Sinai conditions. M.Sc. Thesis, Fac. Of Environmental Agricultural Sciences, Suez Canal Univ.m Egypt.

Abd El-Galil, K. (2001). Utilization of olive pulp meal in feeding growing rabbits. J. Agric. Sci., Mansoura Univ., 26 (2).727-736.

Abd El-Rahman, G.A.; Abou El-Nasr, H.M.; Ayyat, M.S.; Fayed, A.M. and Nassar, M.S. (2003). Utilization of some agro- industrial by products in fattening lambs on the natural ranges in the South of valley. J. Nutrition and Feeds. 6 (Special issue) 851-865.

Abdel-Samee, A.M.; Ali, A.M.; Mousa, M.R.M. and Abd El-Gaffar, M. A. (2005). Productivity and reproductive of heat stressed rabbits as influenced by nutritional treatments under Sinai conditions. The $4^{\text {th }}$ Inter. Con. On Rabbit Prod. In Hot Clim. Sharm El-Sheikh, Egypt, 265-371.

Abou El-Naser, H. M. and El-Kerdawy, D. M. A. (2003). Effect of complete replacement of the common feed mixture by agro industrial by-product on performance of growing lambs under desert conditions of Egypt. Egyptian J. Nutrition and Feeds, 6 (special issue) : 803-810.

Aguiliera, J. F. (1987). Improvement of olive cake and grape by products for animal nutrition. Proceedings of a Workshop held in lelystad Netherlands.

A.O.A.C. (2010). Official Methods of Aalysis. 6thEdn., Association of Official Analytical Chemists, Washington, DC., USA.

Bassuny, S.M. (1999). Performance of doe rabbits and their weanlings as affected by heat stress and their alleviation by nutritional means under Egyptian Conditions. Egyptian J of Rabbit Science, 9 (1) 73-86.

Ben Rayana, A.; Bergoui, R.; Ben Hamouda, M. and Kayouli, C. (1994). Olive oil cake incorporation for young rabbit feeding. $J$. World Rabbit Science, 2: 127-134.

Beyen, A.C. (1988). Dietary fat level and growth performance by rabbits. J. Appl. Rabbit Res., 11: 21-29.

Cheeke, P. R.; Patton, N.M.; Lukefair, S. O. and McNitt, J.I. (1987). Rabbit production. The interstate Publishers and Printers, Inc., Danville, Illinois, U.S.A.

Christodoulou, V.; Bampidis, V. A.; Robinson, P. H. ; Israilides, C. J.; Giouzelyiannis, A. and Vlyssides, A. (2007). Nutitional and net energy value of fermented olive wastes in rations of lactating ewes. Czech, J. Anim. Sci., 52 (12): 456-462. 
Christodoulou, V.; Bampidis, V.A.; Israilides, C.J.; Robinson, P.H.; Giouzelyiannis, A. and Vlyssides, A.(2008). Nutritional value of fermented olive wastes in growing lamb rations. Animal Feed Science and Technology, 141: 375-383.

Duncan, D.B. (1955). Multiple Range and Multiple F-test Biometrics, 11: $1-42$.

El-Basiony, A.Z.; Sabra, M.M.; Mansour, A.M. and Zonkol, K. E. (2005). Effect of a partial replacement of soybean proteins by some untraditional sources on productive performance of growing New Zealand white rabbits. Egyptian J. Nutrition and Feeds, 8 (1) Special Issue , 949-961.

El-Kerdawy, D.M.A. (1997). Olive pulp as a new energy source for growing rabbits. Egyptian Journal of Rabbits Science, 7 (1): 1-12.

El-Sayaad, G.A. (2002). New feedstuffs resources in rabbit nutrition. Proceedings of the $3^{\text {rd }}$ Sci. Conf. on Rabbit Prod. In Hot Climates, 8-11 October Harghada, Egypt pp:461-467.

El-Sayed, E.L.; Shehata, S. and Abou Amo, F. (1996). Evaluation of olive pulp cake in complete diets for sheep in western desert of Egypt. Menofia, J. Agric. Res., 21: 1215.

Fayed, A.M.; Youssef, K. M. and Abou El-Nasr, H.M. (2001). Nutritional performance of goat fed non- conventional diets based on olive pulp in Sinai. Egyptian J. Nutrition and Feeds, 1: 81-89.

Gad, A.E.; Teama, F.E.I. and Mostafa, M.M. (2008). Effect of different concentration of olive pulp on body weight and some biochemical parameters in Friesian calves. Isotope and Rad. Res., 40 (4) (Suppl.1).1195-1204.

Ghazalah, A.A. and El-Shaat, A.A. (1994). Digestibility and acceptability of some agro - industrial by - products by rabbits. J. of Egyptian Poultry Science, 14: 401-422.

Hussein, A.F.; Khalil, F.A.; El-Fouly, M.A. and Amin, S.O. (1999). Reproductive and blood biochemical parameters of New Zealand white rabbit does fed diet partially substituted with broiler litter. Egyptian J. of Rabbit Science, 9 (1): 53-60.

Igwebuike, J.U.; Anugwa, F.O.I.; Raji, A.O.; Ehiobu, N. G. and Kiurior, S.A. (2008). Nutrient digestibility, Haematological and serum biochemical indices of rabbits fed graded levels of Acacia albida pods. ARPN Journal of Agricultural and Biological Science, 3 (4), July: 33-40.

Lotfollahian, H. and Hosseini, S.A. (2007). Evaluation of metabolizable energy values of some feeding stuffs. Pakistan Journal of Biological Science, 10 (6): 995-997. 
Mahmoud, S. A.; Magouze, F. I.; El-Kelawy, H.M.; Homouda, I.A. and Gad Alla, S.A.Z. (1998). Productive and reproductive performance of rabbits fed diets containing different agricultural by-products. 2. Reproductive performance of male and female rabbits. Egyptian Journal of Rabbit Science, 8 (1): 61-68.

Martin, Garcia, A.I.; Moumen, A.; Yanez-Ruiz, D.R. and Molina, Alcaide, E. (2003). Chemical composition and nutrients availability for goats and sheep of two-stage olive cake and olive leaves. Animal Feed Science and Technology. 107: 61-74.

Mehrez, A. Z. and Mousa M. R. M. (2011). Growth performance of rabbits fed olive pulp in North Sinai. Asian Journal of Animal Sciences, 5(5): 317-329.

Moic, B.; Pavic, V.; Vnucec, I.; Prpic, Z.; Kostelic, A. and Susic, V. (2007). Effect of olive cake on daily gain, carcass characteristics and chemical composition of lamb meat. Czech J. Anim. Sci., 52 (2): 31-36.

Molina-Alcaide, E. and Yanez- Ruiz, D.R. (2008). Potential use of olive by - products in ruminant feeding. A review. Animal Feed Science and Technology, 147: 247-264.

Molina Alcaide, E.; yanez Ruiz, D.; Moumen, A. and Martin Garcia, I. (2003). Chemical composition and nitrogen availability for goat and sheep of some olive by-products. Small Ruminant Research, 49: 329-336.

Mostafa, M.R. M.; Salam, R.; Lashin, M. E. and Abdu, A.A. (2003). Utilization of olive cake in fattening rations of Rahmani lambs. $J$. Nutrition and Feeds (Special Issue): 811-820.

Mousa, M.R.M. (2000). Effect of feeding olive pulp on productive performance of Awassi ewes and their lambs under subtropical conditions. J. Agric. Sci. Mansoura Univ., 25 (8): 4967-4975.

Mousa, M.R.M. (2001). Effect of fattening system of lambs under North Sinai conditions on some performance and metabolic parameters. $J$. Agric. Sci., Mansoura Univ., 26 (2): 715-726.

Mousa, M.R.M. and Abd El-Samee, A. M. (2002). Effect of olive pulp feeding on the growth performance and some related blood biochemical changes of growing rabbits under semi- arid conditions. Egyptian Journal of Rabbit Science, 12 (1): 59-68.

Mousa , M.R.M. and Shetaewi, M.M. (2002). Milk yield and growth rate as influenced by feeding olive pulp and acacia shrubs for awassi sheep under semi- arid conditions. Annals of Agric. Sci. Moshtohor, 40 (2): 843-856. 
Mousa, M.R.M. and Shetaewi, M.M, (2003). Productive and reproductive performance of New Zealand White doe rabbits as affected by soybean meal levels under semi-arid conditions of North Sinai. Egyptian Journal of Rabbit Science, 13(1): 21-36.

Moustafa, S.M.S.; Mahgoub, A.A.S.; Sallam, M. T.; Abd El-Ghani, A.A. and Deraz, T.A. (2008). Evaluation of olive pulp waste for Egyptian lactating buffaloes. J. Agric. Sci. Mansoura Univ., 33 (30): 1745-1755.

Mustafa, M.M.; Saleh, H.M. and El-Fouly, H.A. (2009). Effect of using olive by-product inclusion in lambs diet on productive performance and some blood parameters. Egyptian J. Nutrition and Feeds, 12 (3): Special Issue: 253-262.

Onifade, A.A. and Tewe, O.O. (1993). Alternative tropical energy feed resources in rabbit diets. Growth performance, diet digestibility and blood composition. World Rabbit Science, 1: 17-24.

Rabayaa, E.; Abo Omar, J. M. and Othman, R. A. (2001). Utilization of olive pulp in broiler rations. An- Najah Univ. J. Res., 15: 134143.

Salama, H.A.; Salama, R.; El-Shaer, H. M. and Afifi, A. (1993). Utilization of date seeds and olive pulp as supplementary feed for grazing pregnant and lactating sheep and goats in Sinai. J. Agric. Sci. Mansoura Univ., 18 (60): 1633-1644.

Salwa, B. Abd El-Hady; Abd El-Ghani , A. I. and El-Ganzory, E. H. (1999). Effect of sugar beet tops hay and silage in comparison to berseem on digestibility, reproductive performance and some blood plasma constituents of rabbits. Egyptian J. of Rabbit Science, 9 (1): $1-11$.

Sarhan, M.A. (1995). Evaluation of different protein sources in rabbit nutrition. Ph. Thesis, Dept. of Poul. Prod. Faculty of Agric. Mansoura Univ., Egypt.

SAS, (2004). Statistical Analysis System. Users Guide, Statistics. SAS Institute, Cary, North Carolina.

Schiemann, R.; Nehring, K.; Hoffman, L.;Jentsch, W.; Chudy, A. (1972). Energetische futterbewertung and energienormen. VEB Deutscher Landwirtschaftsveriag. Berlin. P. 344.

Suliman, A. I. A. and Moustafa, S. M. S. (2008). Effects of ground date seeds as a partial replacer of ground maize on nitrogen metabolism and animal performance of sheep. J. Agric. Sci. Mansoura Univ., 33 (3): 1735-1744. 
Tortuero, F.; Riopenez, J. and Rodiguez, M. L.(1989). Nutritional value rabbits of olive pulp and the effects on their visceral organs. Animal Feed Science and Technology, 25:79-87.

Vlyssides, A. G.; Loizides, M. and Karlis, P. K. (2004). Integrated strategic approach for resuing olive oil extraction byproducts. $J$. Cleaner Prod., 12, 603-611.

Wittouk, P.; Detimmerman, F.; Petry, M. and Van Hove, C. (1992). Azolla as a food for rabbits in Africa. J. Appl. Res., 15: 1058-1062.

Yousef, M.I. (2005). Reproductive performance blood testosterone, lipid peroxidation and seminal plasma biochemistry of rabbits as affected by feeding Acacia saligna under subtropical conditions. Food and Chemical Toxicology, 43, 333-339.

Yousef, K.M. (2009). Performance and carcass traits of goats fed agroindustrial by - products supplements as feed block. Egyptian J. Nutrition and Feeds, 12 (1): 99-111.

Youssef, K.M.; Fayed, A.M. and Khamis, H.S. (2001). Productive and reproductive performance of ewes and does fed non- conventional diets based on olive pulp in Sinai. Egyptian J. Nutr. and Feeds, 4 (Special Issue): 591. 


\title{
الاستفادة من تفل الزيتون فى تغذية أمهات ونتاج الأرانب النيو زيلاندى الأبيض تحت ظروف شمال سيناء
}

\author{
محمد رضا محمد موسى \\ كلية العلوم الزر اعية البيئية بالعريش - جامعة قناة السويس- ج.م.ع. موند
}

أجرى هذا البحث فيى مزرعة الأرانب التابعة لقسم الإنتاج الحيو انى بكلية العلوم

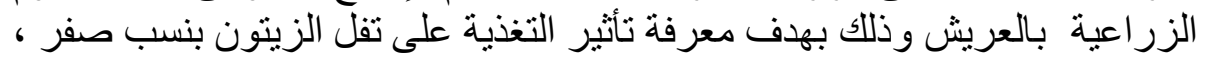

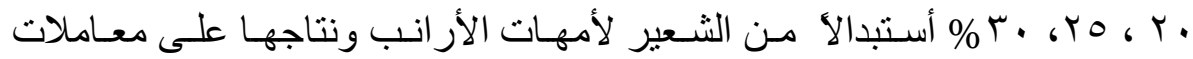

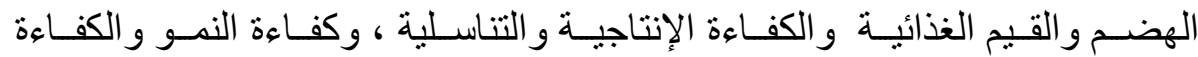

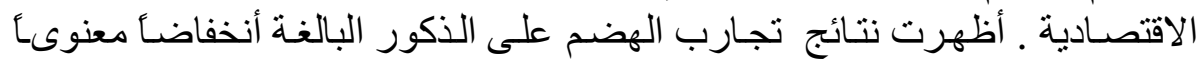

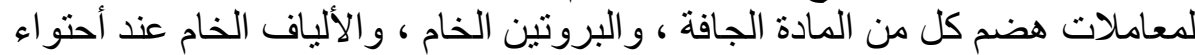

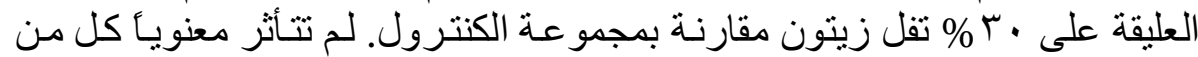

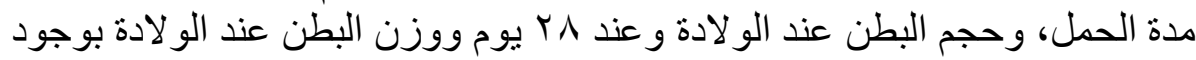

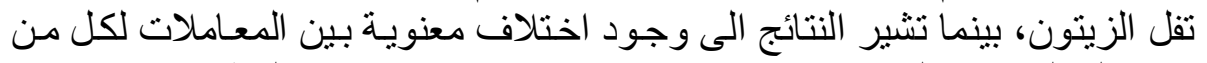

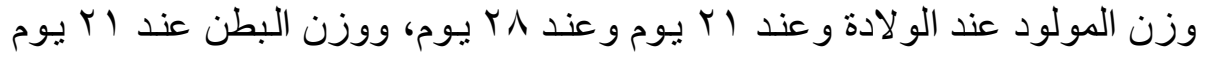

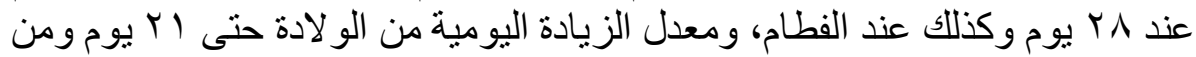

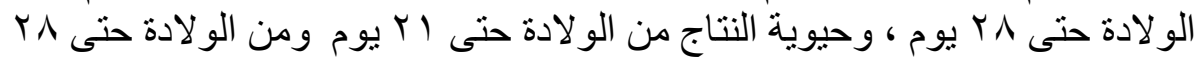

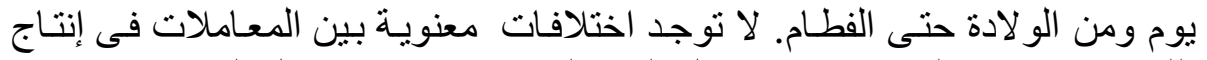

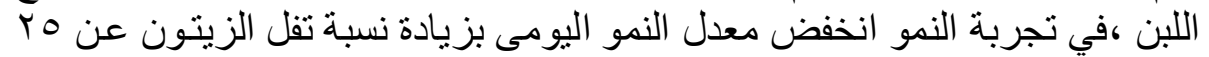

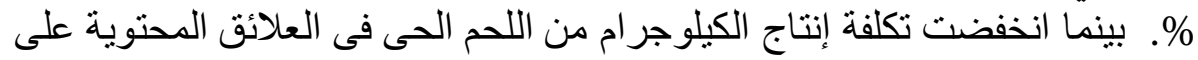
تفل الزيتون مقارنة بمجمو عة الكنترول.

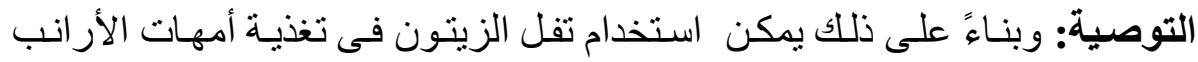

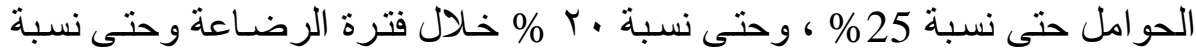

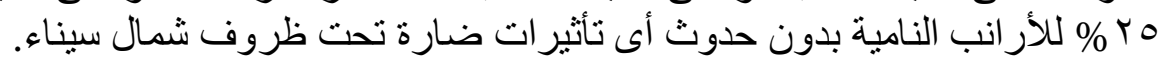

